International Journal of Agriculture, Environment and Bioresearch

Vol. 5, No. 04; 2020

ISSN: $2456-8643$

\title{
MICROFLORA ASSESSMENT OF SOME SELECTED MEDICINAL PLANTS PARTS
}

\author{
Oyediran, R.I ${ }^{1}$, Asonibare, A. $\mathrm{O}^{2}$, Ariwoola, $\mathrm{O.S}^{3}$, Afeye, A.F $\mathrm{F}^{3}$ and Ademuwagun, A. $\mathrm{A}^{4}$ \\ ${ }^{1}$ Bioscience Department \\ ${ }^{2}$ Pathology Section, Department of Forest Conservation and Protection. \\ ${ }^{3}$ Federal College of Forestry, Ibadan. \\ ${ }^{4}$ Federal college of Forestry Mechanization, Afakka, Kaduna State ,Forestry Research Institute of Nigeria, Ibadan
}

https://doi.org/10.35410/IJAEB.2020.5521

\begin{abstract}
Quality is the basis of reproducible efficacy and safety of herbal drugs, and to ensure the standard of research on herbal medicines, the quality of the plant materials or preparations is of utmost importance. This is because many contaminants and residues that may cause harm to the consumers have been reported. In this research some medicinal plants were selected randomly from BMRC herbal garden of the Forestry research institute of Nigeria, Ibadan to assess the level of microbial loads. Parkia biglobosa, Mormodica charantia, Launea taraxacifolia and Eruca sativa were the plants assessed for Microflora assessment.
\end{abstract}

Keywords: Contaminants, Quality, Herbal and Standard.

\section{INTRODUCTION}

The use of medicinal plants is continually expanding worldwide. The increasing search for therapeutic agents derived from plant species is justified by the emergence of diseases, yet without proper treatment, and the growth of scientific knowledge about the herbal medicines as important treatment alternatives. Therefore, the quality and safety of herbal preparations are also of great concern [1]. The reference [2] explained that quality is the basis of reproducible efficacy and safety of herbal drugs, and to ensure the standard of research on herbal medicines, the quality of the plant materials or preparations is of utmost importance.

With the ever increasing use of herbal medicines and the global expansion of the herbal medicines market, safety has become a concern for both health authorities and the public in many countries. This is because many contaminants and residues that may cause harm to the consumers have been reported [3]. By their origin, herbal drugs are subject to contamination by microorganisms from soil, air and water maybe present potentially pathogenic microorganisms to man. Microbial contamination of medicinal herbal can be influenced by environmental factors such as temperature, humidity and extent of rainfall during pre harvesting and post-harvesting periods, handling practices and the storage conditions of crude and processed medicinal-plant materials. In order to improve the purity and safety of the products, observation of basic hygiene during preparation, standardization of some physical characteristic such as moisture content, $\mathrm{pH}$ and microbiological contamination levels are desirable [1,4,5].The presence of microbial contaminant in non sterile pharmaceutical 10; manufacturers should ensure the lowest possible 
level of microorganisms in the raw material, finished dosage forms and the packaging components to maintain appropriate quality, safety and efficacy of the natural products [9].

\section{Brief Review on Test Plants}

Parkia biglobosa is a deciduous tree that belongs to Fabaceae family and it is commonly called African locust bean.It is called "Iru" in yoruba which is used for seasoning of traditional soups.

Launea taraxacifolia belongs to Asteraceae family which is a perennial plant. It can be used for treatment for vomitting, teeth pain and diabetes

Eruca sativa Mill. Is an edible plant that belongs to Brassicaceae family and popularly called Salad Vegetable. It is used as leaf vegetable for its fresh peperry flavor .Well known for its therapeutic properties as an astringent, aphrodisiac, diuretic, digestive, emollient, tonic, depurative, laxative, rubefacient and stimulant.

Mormodica charantia commonly known as (bitter melon) belongs to Cucurbitaceae family. It is used in the treatment of various degenerative diseases (Antidiabetic, Abortifacient, contraceptive, Pneumonia, Leprosy and Antihelminthic).

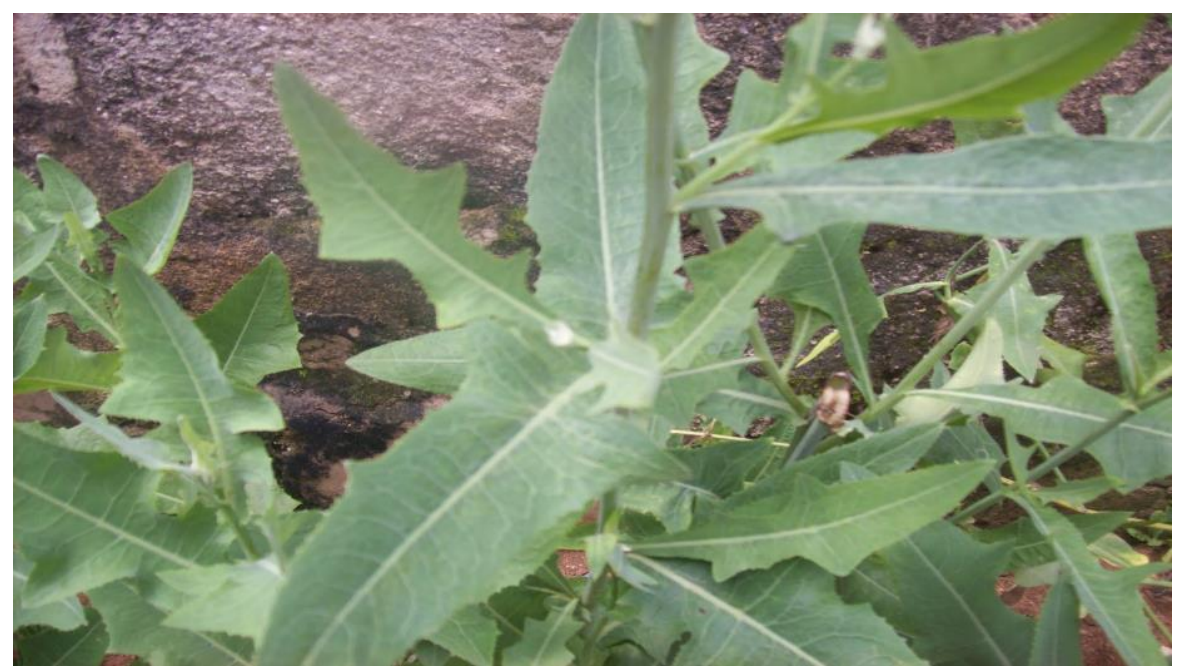

Fig. 1. Launea taraxacifolia 
International Journal of Agriculture, Environment and Bioresearch

Vol. 5, No. 04; 2020

ISSN: $2456-8643$

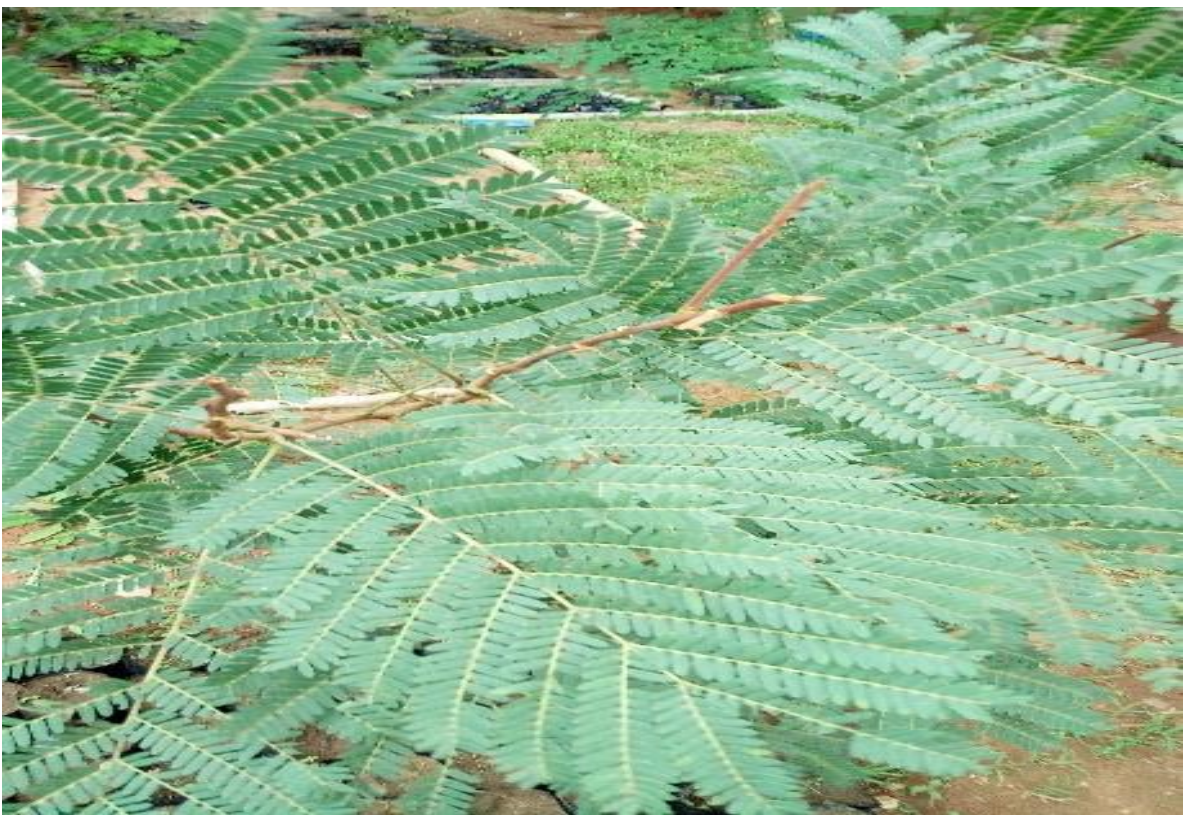

Fig. 2 Parkia biglobosa

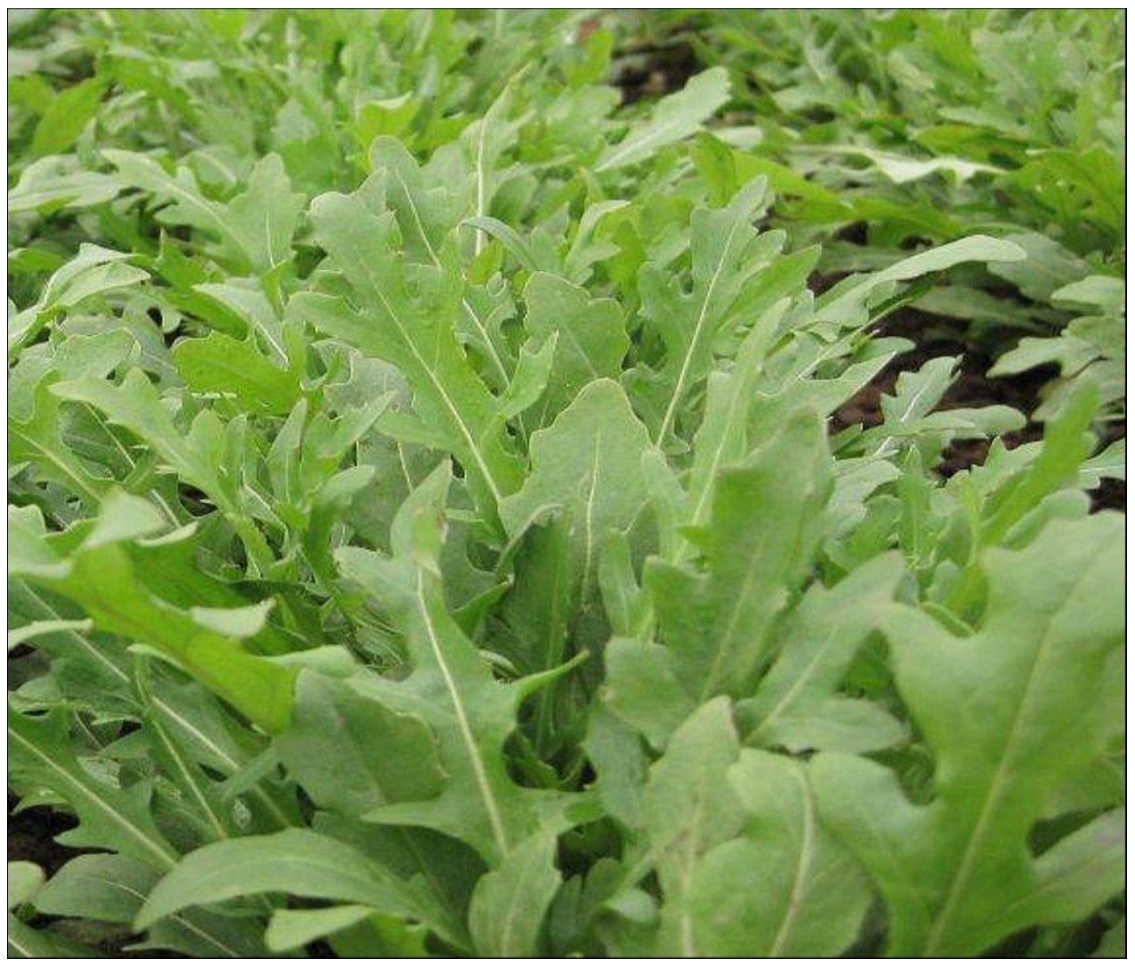

Fig. 3. Eruca sativa 


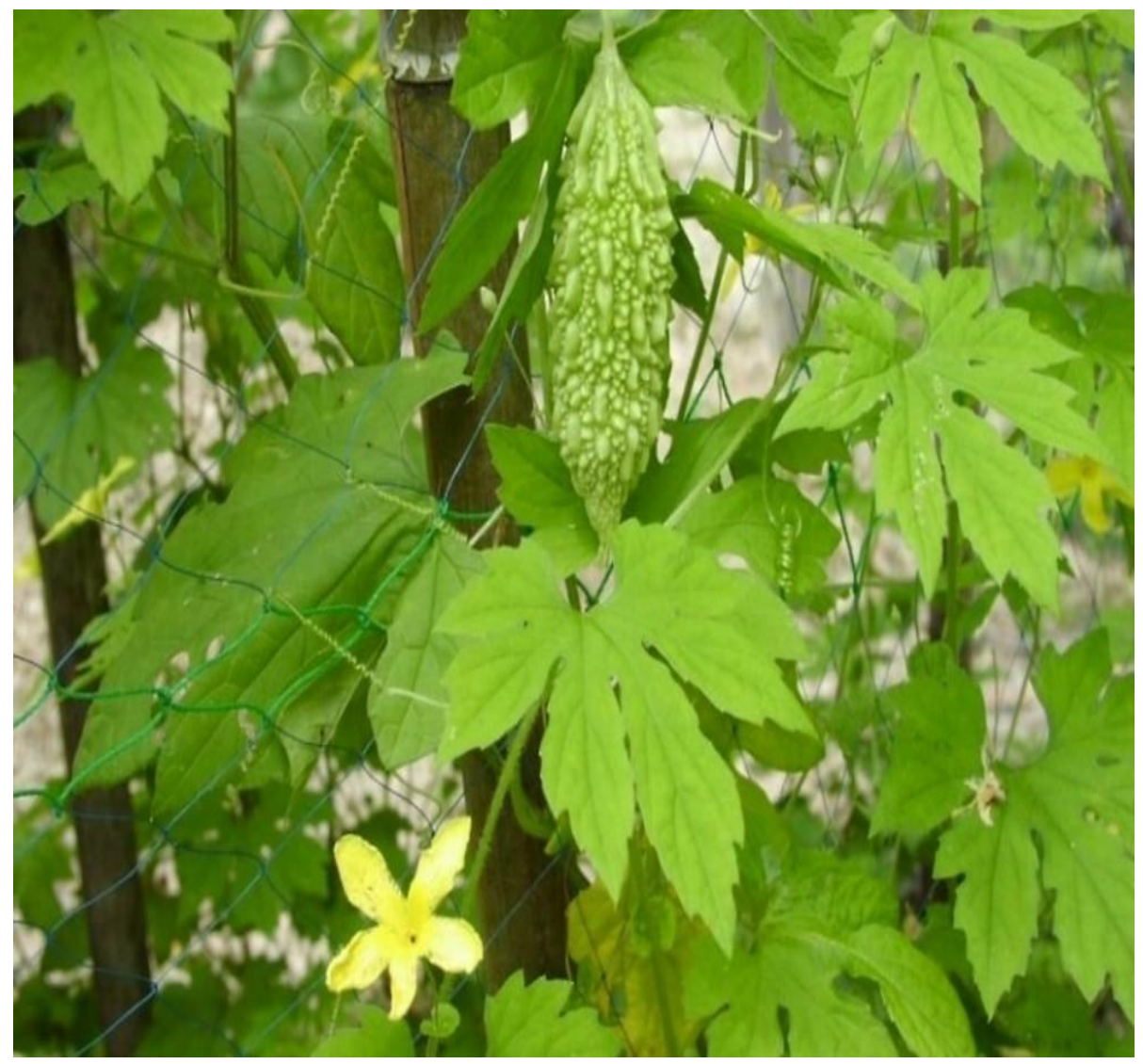

Fig. 3 Mormodica charantia

\section{METHODOLOGY}

\section{Collection of the plant material}

The medicinal plants selected for the present investigation are Parkia biglobosa, Mormodica charantia, Launea taraxacifolia and Eruca sativa and they were collected from their natural habitats. Disease free parts of the plants were cut with the help of a sterile scalpel and placed in sterile plastic bags to store the material for isolation.

\section{Isolation of bacteria}

\section{Surface sterilization of the plant material}

The method most frequently utilised to detect and quantify bacteria involves isolation from surface-sterilized host plant tissues. Isolation was carried out under aseptic conditions. Different symptomless parts of the selected ethnomedicinal plants such as stem cuttings and leaves were used for the isolation of bacteria. The collected plant material used for the isolation was first 
Vol. 5, No. 04; 2020

ISSN: $2456-8643$

surface sterilized following the method of Santos et al. (2003) with few modifications. Plant material was cleaned by washing several times under running tap water and then cut into small pieces. Surface sterilization was performed by sequentially rinsing the plant material with $70 \%$ ethanol $\left(\mathrm{C}_{2} \mathrm{H}_{5} \mathrm{OH}\right)$ for 30 seconds, then with $0.01 \%$ mercuric chloride $\left(\mathrm{HgCl}_{2}\right)$ for 5 minutes followed by $0.5 \%$ sodium hypochlorite $(\mathrm{NaOCl})$ for $2-3$ minutes and finally with sterile distilled water for 2-3 times. Plant materials were then dried in between the folds of sterile filter papers.

\section{Isolation of the bacteria}

After proper drying, the surface sterilized plant material i.e. Stems and leaves were cut into smaller pieces and each piece was placed on Nutrient agar medium supplemented with chloramphenicol (100 mg/ml). Similarly, stems were cut vertically into small segments to expose the inner surface and then inoculated on the Nutrient Agar plates. Six explants were put on each Nutrient agar plate. All the plates were incubated at $28^{\circ} \mathrm{C}$ for $24 \mathrm{hrs}$ to promote the growth of endophytes and were regularly monitored for any microbial growth. On observing the microbial growth, sub culturing was done. Each bacteria culture was checked for purity and transferred to freshly prepared Nutrient Agar plate. Appropriate controls were also set up in which no plant tissues were inoculated.

The microorganisms Staphylococcus aureus, Pseudomonas aeruginosa, , Escherichia coli and were investigated as described by various authors[10, 11] with slight modification. To determine the presence of bacterial contaminants, 10 grams of a herbal powder was dispersed in the medium and made to $100 \mathrm{mls}$ while for liquid samples, $10 \mathrm{ml}$ was diluted to $100 \mathrm{mls}$ by adding soybean casein digest medium and then incubated.

For isolation of the S. aureus, a portion of the enrichment culture medium was spread on the surface of the Vogel-Johnson agar medium and manitol-salt agar which were freshly prepared according to manufacturer's instructions. The plates were incubated at $37{ }^{\circ} \mathrm{C}$ for twenty four hours under aerobic conditions. Colonies showing golden yellow colour or colourless were considered to be $\mathrm{S}$. aureus. The pure isolates were further subjected to gram staining for microscopy, biochemical test such as catalase as well as coagulase to confirm the identity of S. aureus. A portion of the enrichment culture medium was streaked on centrimide agar medium for detection P. aeruginosa.

To detect E. coli, fluid lactose medium was added to $10 \mathrm{mls}$ of the sample to make $100 \mathrm{mls}$. Fluid lactose enrichment was streaked onto differential MacConkey agar plates for E.coli and incubated at $44{ }^{\circ} \mathrm{C}$ for 24 hours. Inoculum from E. coli medium was then streaked onto the surface of Eosin methylene blue (EMB) agar and incubated for 24 hours. Dark colonies with metallic sheen indicated the presence of lactose fermenters. The colonies were further subjected to indole, motility, Voges Proskaur and citrate biochemical test as described by Prescott et al [12]

\section{Determination of viable counts}

The herbal samples were subjected to the following examinations: total aerobic viable count (TAVC), viable counts of Staphylococcus aureus, E.coli, Pseudomonas aeruginosa, Bacillus thurigenisis and Pseudomonas flouresence by pour plate method based on the method by Okunlola et al and Enayatifard et al [11] with slight modification. 
Serial dilutions of the samples were used so that the number of colony forming units (CFU) in petri dishes wound be less than 300. One $\mathrm{ml}$ aliquots in duplicates of each dilution sample were pipetted onto separate sterile petri dishes $(9 \mathrm{~cm}$ in diameter). For total viable counts $20 \mathrm{ml}$ of nutrient medium for cultivation of bacteria while appropriate selective medium was used for pathogenic bacteria under investigation. After solidification of the soft agar the petri dishes were incubated in duplicates at $37{ }^{\circ} \mathrm{C}$ for $48-72$ hours for bacterial counts and at $44{ }^{\circ} \mathrm{C}$ for E.coli. After incubation the number of colony forming units was recorded for each plate.

\section{RESULTS AND DISCUSSION}

A total of five bacteria species (Table 1) were isolated from the four healthy ethnomedicinal plants under investigation. Bacterial isolated from different ethnomedicinal plants in which two are pathogenic and disease causing bacteria (Escerichia coli and Staphylococcus aureus) while the three others are known to be plant growth promoters. Parkia biglobosa was found not to carry any of the pathogenic bacteria isolated but were found in all other test plants. This may possibly be attributed to the fact that most of these test plants are crawling plants and not as raised above the ground level compared to Parkia biglobosa.

Pseudomonas aeruginosa, Bacillus thuringiensis and Pseudomonas flourescens were found to be available in all test ethnobotanical plants, they have roles they play in the growth and health of plants because of their plant growth promoting traits.

Table 1.

\begin{tabular}{|c|c|c|c|c|c|c|}
\hline $\begin{array}{l}\text { Medicinal } \\
\text { Plants }\end{array}$ & Bacterial load & $\begin{array}{l}\text { Staphylococcus } \\
\text { aureus }\end{array}$ & $\begin{array}{l}\text { Escherichia } \\
\text { coli }\end{array}$ & $\begin{array}{l}\text { Pseudomonas } \\
\text { aeruginosa }\end{array}$ & $\begin{array}{l}\text { Bacillus } \\
\text { thurigenisis }\end{array}$ & $\begin{array}{l}\text { Pseudomonas } \\
\text { flouresence }\end{array}$ \\
\hline $\begin{array}{l}\text { Parkia } \\
\text { biglobosa }\end{array}$ & $1.46 \times 10^{6} \mathrm{cfu} / \mathrm{g}$ & - & - & + & + & + \\
\hline $\begin{array}{l}\text { Mormodica } \\
\text { charantia }\end{array}$ & $4.8 \times 105 \mathrm{cfu} / \mathrm{g}$ & + & + & + & + & + \\
\hline $\begin{array}{l}\text { Launea } \\
\text { taraxacifolia }\end{array}$ & $1.35 \times 10^{6} \mathrm{cfu} / \mathrm{g}$ & + & + & + & + & + \\
\hline Eruca sativa & $1.22 \times 10^{6} \mathrm{cfu} / \mathrm{g}$ & + & + & + & + & + \\
\hline
\end{tabular}

\section{CONCLUSION}

The purpose of consuming medicinal plants is to be used in the treatment of ailments, diseases or Infections, but the safety of these plants for consumption is important and should be properly considered to avoid introducing a deadlier disease than the one trying to get treated. This research discovered that some of the bacterial isolated from the plants are pathogenic and causes 
disease if consumed, so proper care of plants materials should be put in place before preparing them for consumption and location of the plants should also be considered. Therefore there is need for enlightenments especially in rural communities where people solely depends on plantderived medicine is common

\section{REFERENCES}

1. Kirmani, M.Z., Sheikh Mohiuddin, S., Naz, F., Naqvi, I.I. and Zahir, E., (2011). Determination of some toxic and essential trace metals in some medicinal and edible plants of Karachi city Pakistan, Journal of Basic and Applied Sciences, Vol. 7, No. 2, pp. 89-95.

2. Bin, C., Xiaoru, W. and Lee, F.S.C., (2001). Pyrolysis coupled with atomic absorption spectrometry for determination of mercury in Chinese medicinal materials, Analytica Chimica Acta, 447(1-2), pp. 161-169.

3. Singh, R.P., Tripathi, R.D., Sinha, S.K., Maheshwari, R. and Srivastava, H.S., (1997). Response of higher plants to lead contaminated environment, Chemosphere, 34, pp. 2467-2493.

4. Kudirat, L.M. and Funmilayo, D.V., (January 2011). Heavy metal levels in vegetables from selected markets in Lagos, Nigeria, African Journal of Food Science and Technology (ISSN: 2141-5455), Vol. 2(1), pp. 018-021.

5. Jarup, L., (2003). Hazards of heavy metals contamination, Br. Med. Bull., 68, pp. 167-182.

6. Sobukola, O.P., Adeniran, O.M., Odedairo, A.A. and Kajihausa, O.E., (June 2010). Heavy metal levels of some fruits and leafy vegetables from selected markets in Lagos, Nigeria, African Journal of Food Science, Vol. 4(2), pp. 389-393.

7. Adefila, E.O., Onwordi, C.T. and Ogunwande, I.A., (2010). Level of heavy metals uptake on vegetables planted on poultry droppings dumpsite, Archives of Applied Science Research, 2(1), pp. 347-353. 